\title{
Soil and Water Bacteria in the Alaskan Subarctic Tundra
}

\author{
HAROLD J. FOURNELLE ${ }^{1}$
}

\section{INTRODUCTION}

\begin{abstract}
A study undertaken in a tundra area in southwestern Alaska showed that there were considerably greater numbers of bacteria in the soil than in the water. The highest plate count of a soil sample was $15,000,000$ per $\mathrm{gm}$., while of water it was $4,4^{\circ}$ o per $\mathrm{ml}$. These counts were made of samples incubated at $20^{\circ} \mathrm{C}$. Progressively lower counts were obtained at $37^{\circ}, 3^{\circ}-5^{\circ}, 45^{\circ}$, and $55^{\circ} \mathrm{C}$. While fewer kinds of bacteria were found in the soil, the difference between soil and water was not great. It was noted that mesophiles predominated both in numbers and in kinds, followed by psychrophiles and thermophiles, in that order.

Based upon frequency of occurrence, comparable numbers of Gram-negative rods and sporeformers were isolated from soil samples; however, considerably more Gramnegative rods were found in water. Of I I bacterial genera or species identified, there were 8 Gram-negative rods: Achromobacter, Alcaligenes, Flavobacterium, Pseudomonas and 4 coliforms (Aerobacter aerogenes A. cloacae Escherichia freundii and $E$. intermeida). The 3 Grampositive forms identified were: Bacillus, Micrococcus, and Streptococcus faecalis.
\end{abstract}

RÉSUMÉ. Bactéries du sol et de l'eau dans la toundra subarctique de l'Alaska. Une étude entreprise dans une région de toundra dans le sud-ouest de l'Alaska a montré qu'on y trouve un nombre considérablement plus grand de bactéries dans le sol que dans l'eau. Le plus haut comptage sur plaque pour un échantillon de sol fut de $05,000,000$ par gm alors qu'il n'était que de 4,400 , par ml pour l'eau. Ces comptages furent effectués sur des échantillons incubés à $0^{\circ} \mathrm{C}$. On obtint des comptages progressivement plus bas à $37^{\circ}$, $3^{\circ}-5^{\circ}, 35^{\circ}$ et $55^{\circ}$. Le nombre d'espèces de bactéries était un peu plus bas pour le sol que pour l'eau. On a noté que les mésophiles prédominaient aussi bien en nombre qu'en espèces, suivis dans l'ordre par les psychrophiles et les termophiles.

Dans les échantillons de sol, on a isolé des nombres comparables de bâtonnets Gram-négatifs et de sporogènes: par contre, on a trouvé beaucoup plus de bâtonnets Gram-négatifs dans l'eau. Dans les 1 I genres ou espèces de bactéries identifiés, il y avait 8 bâtonnets Gram-négatifs, viz,. Achromobacter. Alcaligenes. Flavobacterium. Pseudomonas, et 4 coliformes (Aerobacter aerogenes, $A$. cloacae, Escherichia freundii et $E$. intermedia). Les trois formes Gram-positives identifiées étaient Bacillus, Micrococcus et Streptoccocus faecalis.

РЕЗЮМЕ. Почвенные и водные бактерии в Субарктической тундре Аляски. Исследование в зоне тундры Северо-Западной Аляски показало, что в почве находится значительно больше бактерий, чем в воде. Самое большое количество почвенного образца, установленное счетной пластинкой, было $15,000,000$ /грамм, в то время как в воде это количество достигало только 4,400/мл. Эти данные получены инкубируя при 20Ц. Последовательное уменьшение количества было установлено при $37^{\circ}, 3-5^{\circ}, 45^{\circ}$ и $55^{\circ}$ Ц. Так как в почве было найдено меньше бактерий, то различие меяду почвой и водой уменьшилось. Мезофилы преобладали количественно и качественно, ва ними следовали психрофилы и термофилы.

Вазируясь на их частоте, сравнимые числа грам-отрицательных палочек и спорообразующих микроорганизмов были изолированы из почвенных образцов; однако в воде найдено значительно больше грам-отрицательных палточек. Иа 11 родов и видов определенных бактерий 8 были грам-отрицательные палючки: Achromobacter, Alcaligenes, Flavobacterium, Pseudomonas, и 4 кишечные формы: Aerobacter aerogenes, $A$. cloacae, Escherichia freundi, $E$. intermedia. Три грамположительные формы были определены как: Bacillus, Micrococcus $n$ Streptococcus faecalis.

1Division of Research Grants, National Institutes of Health. Public Health Service. Bethesda Maryland. Formerly bacteriologist, Arctic Health Research Center, Public Health Service, Anchorage, Alaska. 
Studies on the microbiological flora of arctic and subarctic soils and waters have dealt mainly with the bacterial content. McBee and McBee (1956) reported on the presence of thermophilic and coliform bacteria in the soil and water in the area of Point Barrow, Alaska, while McBee and Gaugler (1956) identified I 5 thermophilic cultures from that area. Boyd (1958, 1959), Boyd and Boyd (1962a; 1962b; 1963; 1964), and Brockman and Boyd ( 1963 ) made a series of studies on the microbiology and on the chemical and physical characteristics of soils and waters taken, for the most part, along the arctic coast of Alaska. DiGiovanni et al. ( 1962 ) studied the sanitary aspects of Greenland soil and lake water. In a more recent report on the microbiology of Canadian permafrost, Ivarson (1965) presented bacterial, actinomycetal, and fungal plate counts and identified some fungal genera. These investigators identified many of the bacteria they isolated and reviewed the literature on the microflora in arctic soils and waters.

The present study, made in conjunction with a study on the survival of enteric bacteria in nature in a tundra area in southwestern Alaska, was conducted in the vicinity of the Eskimo village of Napaskiak. The village, which in 1957 had a population of 129 , is located on the Kuskokwim River, about 5 miles downstream from Bethel and 400 air miles west of Anchorage. The area, described by Williamson (I957), is in a transitional region where the tundra of the Kuskokwim-Yukon delta meets the sparse birch-spruce forest of the interior. There are numerous ponds and the Kuskokwim gives rise to many streams and sloughs. Hilliard (1958) described the ponds as low in minerals and high in humic colloids. The soil is boggy, having a tough, brownish mat on the surface and a dark, humus-rich composition underneath. The year-round climate of the delta is more moderate than that of the interior. The mean annual temperature is $30^{\circ} \mathrm{F}$., with a monthly mean for July of $55^{\circ} \mathrm{F}$. and for January of $6^{\circ} \mathrm{F}$. Only 55 days of the year are clear; the remainder have cloudy skies to varying degrees. The annual rainfall is 19 inches.

\section{STUDY PLAN AND METHODS}

The sampling area was within a 6-mile radius of the village. In August I957, a preliminary investigation was made in which 3 soil and 5 water samples were collected to get an idea of the numbers and kinds of microorganisms (bacteria, molds, and yeasts) to be expected. In September 1957, 6 samples of soil and 6 samples of water were taken, and in June 1958 , Io samples of each were collected.

The Arctic Health Research Center maintains a cabin in Napaskiak for its field workers who are carrying out prolonged studies in the area. The author used the cabin for living quarters and as a field laboratory. The laboratory was equipped for initial bacteriological and mycological examinations, that is, for the determination of microbial numbers and for 
TABLE I

\begin{tabular}{llcr}
\hline Bacteria & Medium & $\begin{array}{c}\text { Temperature of } \\
\text { incubation, }\end{array}{ }^{\circ} \mathrm{C}$. & $\begin{array}{r}\text { Lergth of } \\
\text { incubation }\end{array}$ \\
\hline Thermophile & $\begin{array}{l}\text { Tryptone-glucose-extract } \\
\text { (TGE) agar }\end{array}$ & 55 & 48 hrs. \\
Mesophile & do. & $45 ; 37 ; 20$ & $48 ; 48 ; 72$ hrs. \\
Psychrophile & do. & $3-5$ & $7-9$ days \\
Coliform & Violet-red-bile (VRB) agar & 37 & 24 hrs. \\
Enterococcus & SF medium & 45 & $2-4$ days \\
Anaerobe & Fluid thioglycollate medium & 37 & $2-4$ days \\
\hline
\end{tabular}

making isolations. Identification of the bacteria was made in the central laboratory in Anchorage and of the fungi in the Public Health Service's Sanitary Engineering Center in Cincinnati.

Table I indicates the medium as well as the temperature and the duration of incubation for the bacteria sought. Bacteriological media were Difco products. Incubation temperatures of $45^{\circ}$ and $20^{\circ} \mathrm{C}$. were used to separate bacteria into thermophiles, mesophiles, and psychrophiles, and to define limits of their respective growth ranges.

Equipment included 3 small electric incubators and 2 small, undercounter-type refrigerators. One of the refrigerators was provided with a heating element and thermostat to serve as the $20^{\circ} \mathrm{C}$. incubator whereas the other was set at a low temperature to serve as the $3^{\circ}-5^{\circ} \mathrm{C}$. incubator. The incubators, an agar-tempering bath, and the lights were all operated by a 2,500-watt portable gasoline generator. Disposable plastic Petri plates were used for plating agar media. Agar and liquid media, and dilution blanks were prepared in the Anchorage laboratory and transported to the field in screw-capped bottles and test tubes. A small propane gas torch was found to be a satisfactory substitute for a Bunsen burner. Equipment also included a microscope, bacterial stains, a Beckman (model G) pH meter, and other items required in a bacteriological laboratory.

The author was assisted by a 16 -year-old Eskimo boy, Peter Williams, who provided boat transportation and was helpful in selecting suitable sampling sites because he knew the local terrain. Before soil samples were taken, surface debris was cleared away; then, after digging about 6 in. below the surface, the sample was collected with a sterile spatula and was placed in a sterile container. Water samples were taken about io ft. from the shores of ponds by tossing out a sterile bottle tied to a string and allowing the bottle to sink.

Most examinations were made within 4 to 6 hours of the time that the samples had been collected. Based upon the preliminary study, a range of dilutions of the soils and waters to be examined were made prior to planting them into agar and liquid media. (Soil dilutions were made from an initial 1 : I o dilution whereby a ı gm. portion of the soil sample was added to a $90 \mathrm{ml}$. water blank). A single plate per dilution was poured 'with agar 
TABLE 2. Range and average of bacterial counts on soil and water samples, Napaskiak.

September I 957 ; June $195^{8}$

\begin{tabular}{|c|c|c|c|c|c|}
\hline \multirow[b]{2}{*}{ Sample } & \multirow{2}{*}{$\begin{array}{c}\text { Kind } \\
\text { of } \\
\text { bacteria }\end{array}$} & \multicolumn{2}{|c|}{ September 1957} & \multicolumn{2}{|c|}{ Fune 1958} \\
\hline & & $\begin{array}{l}\text { Range of counts, } \\
\text { per gm. or ml. }\end{array}$ & $\begin{array}{l}\text { Average count, } \\
\text { per gm. or ml. }\end{array}$ & $\begin{array}{l}\text { Range of counts, } \\
\text { per gm. or ml. }\end{array}$ & $\begin{array}{l}\text { Average count } \\
\text { per gm. or } m l \text {. }\end{array}$ \\
\hline Soil & $\begin{array}{c}55^{\circ} \mathrm{C} . \\
45^{\circ} \mathrm{C} . \\
37^{\circ} \mathrm{C} . \\
20^{\circ} \mathrm{C} \\
3^{\circ}-5^{\circ} \mathrm{C} . \\
\text { Coliform } \\
\text { Enterococcus } \\
\text { Anaerobic }\end{array}$ & $\begin{array}{c}0^{*}-1,100 \\
0^{*}-1,700 \\
16,000-33^{0,000} \\
16,000-34^{0,000} \\
1,200-150,000 \\
o \dagger-1,400 \\
o+\dagger \\
62-6,200\end{array}$ & $\begin{array}{c}310 \\
480 \\
127,000 \\
118,000 \\
34,000 \\
230 \\
\text { o† } \\
2,300\end{array}$ & $\begin{array}{c}20-2,100 \\
20-1,600 \\
9,800-1,300,000 \\
62,000-15,000,000 \\
100-1,300,000 \\
0 \dagger-240 \\
\text { oft-0.006 } \\
24^{0-1} 30,000\end{array}$ & $\begin{array}{c}620 \\
660 \\
850,000 \\
1,700,000 \\
150,000 \\
30 \\
<1 \dagger \dagger \\
27,000\end{array}$ \\
\hline Water & $\begin{array}{c}55^{\circ} \mathrm{C} \text {. } \\
45^{\circ} \mathrm{C} . \\
37^{\circ} \mathrm{C} \text {. } \\
20^{\circ} \mathrm{C} \text {. } \\
3^{\circ}-5^{\circ} \mathrm{C} . \\
\text { Coliform } \\
\text { Enterococcus } \\
\text { Anaerobic }\end{array}$ & $\begin{array}{c}0^{*}-1 \\
0^{*}-14 \\
35^{0-920} \\
330-1,600 \\
180-630 \\
5^{-72} \\
\text { of }+0.023 \\
6-240\end{array}$ & $\begin{array}{c}<1^{*} \\
6 \\
700 \\
790 \\
330 \\
23 \\
<1+\dagger \\
63\end{array}$ & 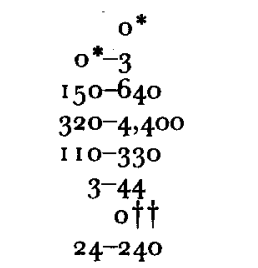 & $\begin{array}{c}0^{*} \\
1 \\
320 \\
1,200 \\
180 \\
14 \\
0+\dagger \\
79\end{array}$ \\
\hline
\end{tabular}

Largest amount of sample used:

* $\mathrm{I}$ ml. of $\mathrm{I}: \mathrm{I}$ o dilution of sample.

† $\mathrm{gm}$. or $\mathrm{I} \mathrm{ml}$.

††roogm. or roo ml. 
media and after suitable incubation time, colony counts were made. Two tubes of each of the liquid media were inoculated with the appropriate dilutions of soil and water, and, after incubation, an enumeration of bacteria was made by determining the most probable numbers (MPN) from tables in Standard Methods (American Public Health Association 1955). A representative sampling of cultures for identification was taken from each medium at each incubation temperature.

\section{RESULTS}

Soil temperatures, taken near the surface in 7 localities, ranged from $0^{\circ}$ to $8.5^{\circ} \mathrm{C}$. The $\mathrm{pH}$ determinations on 9 soil samples ranged from $4.4 \mathrm{I}$ to 7.07 and averaged 5.6o. The temperature range for 15 ponds was between I $0.5^{\circ}$ and $15.5^{\circ} \mathrm{C}$. The $\mathrm{pH}$ values for 20 pond samples gave a range of 6.02 to $7.5^{\circ}$ and an average of 6.92. (These values were fully tabulated in an earlier report (Cooke and Fournelle 1960) along with an enumeration and identification of fungi.)

Bacterial colony counts and MPN counts of soil (moist) and water samples collected in September 1957 and June I $95^{8}$ have been consolidated by sampling period and are shown in Table 2. In general, the soil is a much more productive source of microorganisms than is water. The coliforms were an exception: they were present in all 16 water samples, and in only 5 of the 16 soil samples. The upper limit of the coliform count in soil $(\mathrm{I}, 4 \mathrm{OO}$ per $\mathrm{gm}$.), occurring in soil sample number 4 (September 1957), was very high, whereas the other 5 soil samples taken at that time were negative for these organisms. It was noted that the 5 counts made in the temperature range of $55^{\circ}$ through $3^{\circ}-5^{\circ} \mathrm{C}$. for this one sample were also appreciably higher than those for the other 5 soil samples examined at that time.

The highest colony counts, range and average, were generally found at $20^{\circ} \mathrm{C}$., followed in order by those at $37^{\circ}, 3^{\circ}-5^{\circ}, 45^{\circ}$, and $55^{\circ} \mathrm{C}$. There was no correlation between counts for a given sample; for example, a high count at $20^{\circ} \mathrm{C}$. was not necessarily associated with high counts at other temperatures, nor with high coliform, enterococcus, or anaerobic counts. However, high $20^{\circ}$ and $37^{\circ} \mathrm{C}$. plate counts usually went together.

Coliform colony counts of water samples were low and did not deviate greatly from the averages of the 2 sampling periods. Coliform counts of the 5 positive soil samples (of the 16 examined) varied between o and I, 400 per gm. While I of the other 4 positive soil samples had a coliform count of 240 per gm., 3 of them ranged between 10 and $3^{\circ}$ per gm.

Only 4 of 16 soil samples and $I$ of 16 water samples were positive for enterococci, and these organisms were present in very small numbers (less than I per gm. or ml.).

Anaerobic counts appear to be low. A better approximation was expected with the $37^{\circ} \mathrm{C}$. mesophile plate counts because the organisms which grew in the thioglycollate medium were mainly facultative anaerobes. Smears showed that the organisms were mainly Gram-negative rods (45 per cent) 
TABLE 3. Identification of bacterial isolates from soil and water, Napaskiak.

September I 957; June $195^{8}$

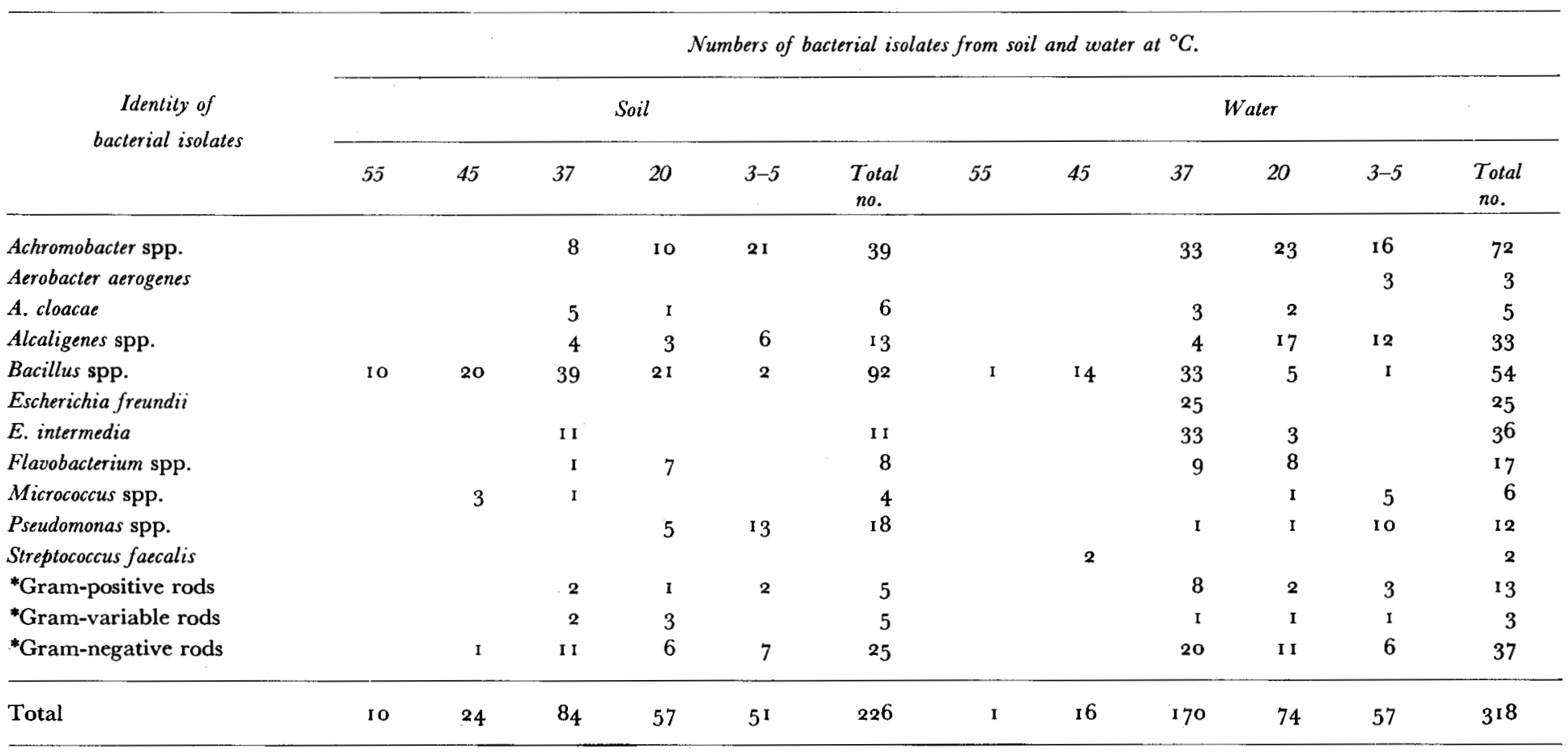

*Unidentified 
and sporeformers (35 per cent), both of which grow well aerobically and anaerobically. No true anaerobes were detected in the thioglycollate cultures examined.

The identity of the bacterial isolates from soil and water as related to the temperatures of incubation is shown in Table 3. Identification was made according to Bergey's Manual (Breed et al. 1957), with no attempts to identify the isolates below the genus designation except for the coliforms and enterococci.

Eleven bacterial genera and species were identified as coming from soil, compared with 8 from water. There was a preponderance of Gramnegative rods in soil and water, making up $4^{2.0}$ and 63.8 per cent, respectively, of the isolated bacteria. The aerobic sporeformer, Bacillus spp., made up 40.7 and 17.0 per cent of the bacteria in soil and water, respectively. In the genus Micrococcus, there were 4 ( $\mathrm{I} .8$ per cent) and 6 isolates (r.9 per cent) from soil and water, respectively. No enterococci were isolated from soil and there were only 2 isolations (o.6 per cent) of Streptococcus faecalis from water. Coliforms made up 7.5 per cent of the bacterial flora in soil, with 2 types being identified (Aerobacter cloacae and Escherichia intermedia), whereas in water, coliforms constituted 21.7 per cent and consisted of 4 species (the 2 above, plus $A$. aerogenes and E. freundii). E. intermedia was found more often than the other 3 coliform species. Of the Gram-negative rods other than coliform, Achromobacter spp. was the most numerous, accounting for I 7.3 and 22.6 per cent of the total cultures from soil and water, respectively. The other 3 Gram-negative rods, Alcaligenes pp., Flavobacterium spp., and Pseudomonas spp. made up 5.8, 3.5, and 8.o per cent of the soil cultures, and $10.4,5.3$, and 3.8 per cent of the water cultures, respectively. Unidentified cultures amounted to $\mathrm{I} 5.5$ and $\mathrm{I} 6.6$ per cent of the totals in soil and water, respectively.

Table 3 also shows the predominant bacterial isolates at the several temperatures of incubation. The aerobic sporeformer, Bacillus spp., was the only organism found at all 5 incubation temperatures in soil and water, and it was isolated more often than any other organism. A tendency toward a predominance of Gram-negative bacilli existed at the 3 lower temperatures $\left(37^{\circ}, 20^{\circ}\right.$, and $3^{\circ}-5^{\circ} \mathrm{C}$.), especially in the water samples. Grampositive forms (rods and cocci) were the main isolates at $55^{\circ}$ and $45^{\circ} \mathrm{C}$. The diversity of identified bacteria was greatest in those isolated at $37^{\circ} \mathrm{C}$., and this decreased progressively at $20^{\circ}, 3^{\circ}-5^{\circ}, 45^{\circ}$, and $55^{\circ} \mathrm{C}$.

\section{DISCUSSION}

Although total numbers of bacteria to be found in subarctic soils and waters can be expected to differ from values obtained in arctic and temperate environments, there are several features common to the bacteria found in each of the 3 areas. On suitability to incubation temperatures, there is ordinarily a preponderance of mesophilic bacteria (those growing best in the $20^{\circ}$ to $45^{\circ} \mathrm{C}$. range) in numbers and kinds. Appearing next, in decreasing order of numbers and kinds, are the psychrophiles (most favour- 
able growth range under $20^{\circ} \mathrm{C}$.) and, finally, the thermophiles (which grow best above $45^{\circ} \mathrm{C}$.). On the second feature, a similarity in the kinds of bacteria is to be expected, that is to say, we are likely to see the same genera and many of the same species in the 3 diverse environments. These features exist because the same microorganisms are known to be widespread in nature.

Many, if not most, soil and water bacteria have a facultative nature with respect to their temperature requirement for growth. While they miay grow best at a given temperature, they are capable of growing at other temperatures. This capability is variable among the different kinds of bacteria; for some the range is very wide, while for others it is relatively narrow. Those bacteria that are truely obligative, in that they grow best at a set temperature or within a very narrow temperature range, are few in number and are found infrequently in nature. The forms that were encountered in this study can be considered as facultative.

According to Boyd (1959), and Boyd and Boyd (1963), coliform organisms are short-lived and do not survive for long periods of time in arctic lake water. This might explain, in part, the low levels found in the ponds at the time of sampling. The infrequency of coliform positives in the soil ( 5 positives in 16 samples) is difficult to explain in view of the fact that these organisms are ubiquitous in nature and are thought to be no more susceptible to adverse environmental conditions than the other Gramnegative bacilli. The one high coliform count $(\mathrm{I}, 400$ per $\mathrm{gm}$.) was on a soil sample taken in September 1957 at a spot several miles from the village and near a path that had been worn by human traffic. This relatively high count may represent recent human or animal defecation since Escherichia intermedia was isolated, a type found in the intestinal tracts of vertebrates. (The other bacterial counts on this sample were also high and were the highest in the series taken during that sampling period). Contrary to what might be expected, $E$. coli, the type species representative of the genus Escherichia and considered to be widely distributed in nature, was not found in either of the two sampling periods. There were only 2 coliform species (in I 7 isolations) taken from the soil, while 4 species (69 isolations) came from water. The bulk of the latter were the 2 coliform intermediates, Escherichia freundii and E. intermedia, constituting 6I isolations, or 88.4 per cent. It is also surprising that there were so few isolations of the 2 Aerobacter species which are soil bacteria.

Little significance can be given to the 2 isolations of the enterococcus, Streptococcus faecalis, since the enterococci make up a smaller portion of the fecal bacterial flora and would be expected to appear in nature in limited numbers. These microorganisms are thought to have as good a capacity to survive in nature as have other non-sporeforming bacteria.

Although 6 of the 32 samples showed anaerobic counts which were the same or slightly higher than the $37^{\circ} \mathrm{C}$. plate counts, the majority of the anaerobic counts were much lower than the plate counts. From the fact that the bacteria found in the $37^{\circ} \mathrm{C}$. plate counts (mainly Gram-negative 
rods and sporeformers) were mainly facultative anaerobes and were thus capable of growing in the anaerobic medium, one would expect that the 2 counts would show better agreement. That they did not may be due, in part, to the method by which the anaerobes were enumerated. The MPN technique where only 2 tubes per dilution are used is imprecise, as it gives only a very rough estimate of the bacterial population. In the 32 determinations made, $26 \mathrm{MPN}$ counts, or 81.2 per cent, were lower than the $37^{\circ} \mathrm{C}$. plate counts. (The MPN technique permits the use of large samples, for example, Ioo gm. or ml., or larger, to show the presence of very few microorganisms.)

The number of Gram-negative rods isolated from the soil approximated the number of sporeformers taken (1 20/102). However, considerably more of the Gram-negative forms were found in water $(240 / 70)$ and the difference appears to be significant. Boyd and Boyd (1963) found that Gramnegative bacteria were predominant in arctic lake water.

As might be expected, there was a similarity in the kinds of bacteria found in the soil and water. However, Aerobacter aerogenes, Escherichia freundii, and Streptococcus faecalis were absent in soil but present in water. The difference could be attributed to sampling in the case of at least 2 of these microorganisms, since few isolations were made. In general, identifications made in this study compare well with those made by Boyd and Boyd ( 1963$)$ in arctic lake water, with the exception that they also isolated Chromobacterium spp.

There is a thermal tolerance and a degree of selectivity for some bacteria at the several incubation temperatures. As Table 3 shows, the growth range for the sporeformer, Bacillus spp., is widest, extending over the 5 temperatures employed. While this organism was dominant at the higher incubation temperatures, it was in the minority at $3^{\circ}-5^{\circ} \mathrm{C}$. Gram-positive rods and cocci were the main forms found at the 2 higher temperatures of incubation. At $55^{\circ} \mathrm{C}$., only the sporeformer, Bacillus spp., was found. At $45^{\circ} \mathrm{C}$., there were 3 types in soil: Bacillus spp., Micrococcus spp., and an unidentified Gram-negative rod, while in water there were 2 types: Bacillus spp. and Streptococcus faecalis. At the intermediate temperatures of $37^{\circ}$ and $20^{\circ} \mathrm{C}$., the dominant organisms were the Gram-negative rods and the sporeformers. At the low temperature of $3^{\circ}-5^{\circ} \mathrm{C}$., the Gram-negative bacilli appeared most often. The greater prevalence of these 2 microorganisms (Gramnegative rods and sporeformers) at the 5 incubation temperatures no doubt had a tendency to obscure and prevent detection and isolation of the less-frequently occurring bacteria. Another factor influencing detection and isolation of bacteria from the plating media was the overgrowth of molds on some plates incubated at $20^{\circ}$ and $3^{\circ}-5^{\circ} \mathrm{C}$.

\section{REFERENCES}

AMERICAN PUblic HEAlth Association, 1955. Standard methods for the examination of water, sewage, and industrial wastes. I oth ed. New York, $522 \mathrm{pp}$. 
BOYD, w. L., 1958. Microbiological studies of Arctic soil. Ecology, 39: 332-36.

Ecology, 40: $49-54$.

BOYD, W. L., and J. W. BOYD, I 962 a. Viability of thermophiles and coliform bacteria in Arctic soils and water. Canadian Fournal of Microbiology, 8:189-92.

83: 429-30.

1962b. Presence of Azotobacter species in polar regions. Fournal of Bacteriology,

1963. A bacteriological study of an Arctic coastal lake. Ecology, 44: 705-10.

- 1964 . The presence of bacteria in permafrost of the Alaskan Arctic. Canadian Journal of Microbiology, 10: 91 7-19.

BREED, R. S., E. G. D. MURRAY, and N. R. SMITH, 1957. Bergey's manual of determinative bacterio$\log y .7^{\text {th }}$ ed. Baltimore: Williams \& Wilkins Co., 1094 pp.

BRockman, E. R., and W. L. Boyd, 1963. Myxobacteria from soils of the Alaskan and Canadian Arctic. Fournal of Bacteriology, 86: 605-6.

COOKE, w. в., and H. J. (н. т.) FOURNelle, ig6o. Some soil fungi from an Alaskan tundra area. Arctic, 13: 266-69.

Digiovanni, C., JR., J. W. Rachlin, R. F. Barquist, E. S. Dooley, and T. R. A. DAVis, ig62. Some microbiological and sanitary aspects of military operations in Greenland. Arctic, I5: 155-59.

HILliaRD, D. K., 1958. Personal communication.

IVARson, $\mathbf{k}$. c., I 965 . The microbiology of some permafrost soils in the Mackenzie Valley, N.W.T. Arctic, I8: 256-6o.

MCBEE, R. H., and V. H. MGBEE, I 956. The incidence of thermophilic bacteria in Arctic soils and water. Journal of Bacteriology, $7^{1}$ : $182-85$.

and L. P. GAUgLer, 1956. Identity of thermophilic bacteria isolated from Arctic soils and waters. Fournal of Bacteriology, 7 I : $186-87$.

Williamson, F. S. L., I957. Ecological distribution of birds in the Napaskiak area of the Kuskokwim River delta, Alaska. Condor, 59: $3^{17-38 . ~}$ 